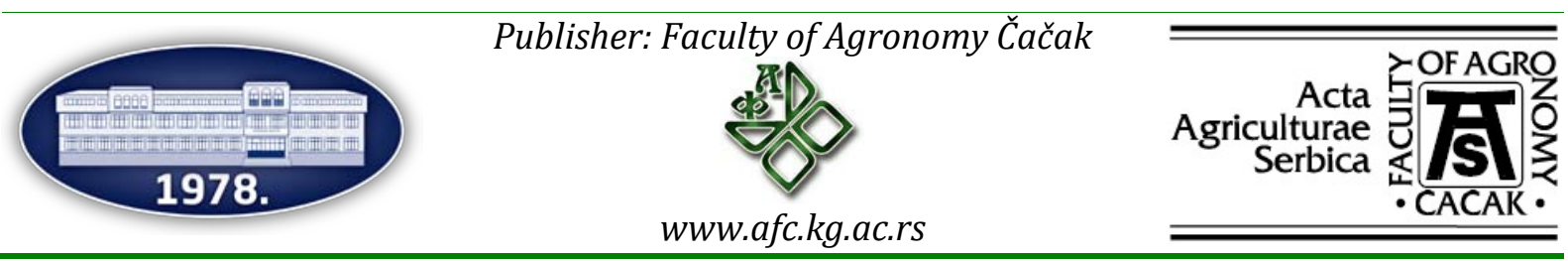

\title{
Seasonal performance of shared silage combine harvesters in a machinery ring
}

\author{
Ranko Koprivica ${ }^{1}$, Biljana Veljković1 ${ }^{*}$, Dušan Radivojević ${ }^{2}$, Tatjana Dedić ${ }^{3}$, Zoran

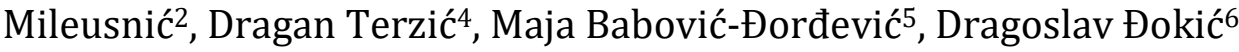 \\ ${ }^{1}$ University of Kragujevac, Faculty of Agronomy in Čačak, Cara Dušana 34, Čačak, Serbia \\ ${ }^{2}$ University of Belgrade, Faculty of Agriculture, Nemanjina 6, Belgrade Zemun, Serbia \\ ${ }^{3} U N$ FAO Regional Office for Europe and Central Asia, Budapest, Hungary \\ ${ }^{4}$ University of Niš, Faculty of Agriculture in Kruševac, Kosančićeva 4, Kruševac Serbia \\ ${ }^{5}$ University of Priština, Faculty of Agriculture, Kosovska Mitrovica - Lešak, Kopaonička bb, 38219 Lešak, Kosovo and \\ Metohia, Serbia, \\ ${ }^{6}$ Institute for Forage Crops, Globoder 37251 Kruševac, Serbia
}

*Corresponding author: biljavz@kg.ac.rs

Received 22 June 2020; Accepted 9 July 2020

\begin{abstract}
A B S T R A C T
The article presents the results of monitored operation of combines during the first season of their joint use for silage preparation in the northern part of Montenegro in machinery rings in the municipalities of Bijelo Polje, Berane and Pljevlja. The seasonal performance was determined for a total of 6 combines, of which only one was used for the preparation of silage from whole corn plants, one combine was used for preparing silage from cuts, and four combines were intended for direct mowing and ensiling of grass. The research included 7 machinery rings and 45 farmers, of which 11 (24.44\%) shared harvesters for the preparation of silage from grass, alfalfa, a mixture of legumes, and grain. During the season, the shared harvesters worked 45 days and achieved an output of 23.95 ha and $687.75 \mathrm{t}$ of silage.

For the preparation of silage from whole corn plants in 2 machinery rings, a joint combine was used by 9 farmers. The total seasonal performance of the combine was 14.9 ha of harvested land, and 468.45 t of corn silage for 19 days of work.

The extent of use of shared silage combine harvesters depends on plot size, area under fodder plants, organization of work, output of the combine, optimal dates for cultural operations, and weather conditions i.e. the number of days suitable for work, etc.

Keywords: machinery ring, shared silage combine, silage harvester performance, silage of corn, grass, legumes and oats.

\section{И 3 В $О$ Д}

У раду су приказани резултати праћења рада комбајна у току прве сезоне заједничког коришћења у припремању силаже у Северном делу Црне Горе у машинским прстеновима у општинама Бијело Поље, Беране и Пљевља. Утврђен је сезонски учинак укупно 6 комбајна, од којих је само један за припремање силаже од целе биљке кукуруза, један комбајн је за силирање силомасе из откоса, а четири комбајна су намењена за директно кошење и силирање трава.

Истраживањима је обухваћено 7 машинских прстенова и 45 фармера, од којих је 11 (24,44\%) заједнички користило комбајне за припрему силаже од трава, луцерке, мешавине легуминоза и жита. У току сезоне заједнички коришћени комбајни су радили 45 дана и остварили учинак од 23,95 ha и 687,75 t сило масе.

За припрему силаже од целе биљке кукуруза у 2 машинска прстена заједнички комбајн је користило 9 фармера. Укупан сезонски површински учинак комбајна је 14,9 ha, а масени 468,45 t силаже кукуруза за 19 дана рада.

Обим коришћења заједничких комбајна за силажу зависи од величине парцеле, површина под крмним биљем организације рада, експлоатационог учинка комбајна, оптималних агротехничких рокова, временских услова, односно броја погодних дана за рад и др.
\end{abstract}

Кључне речи: машински прстен, заједнички силокомбајни, учинак силокомбајна, силажа од кукуруза, трава, легуминоза и овса.

\section{Introduction}

The introduction of new technologies and highly productive machines in animal feed production with minimal costs of own investment is possible only through the joint purchase and use of agricultural machinery in the machinery ring (MR). The key reasons for uniting farmers in the MR in the north of Montenegro are improvement of agricultural production, more efficient use of natural agricultural resources, more economical work, and rational use of machines in order to reduce production costs and increase farm profits.

As reported by Baranai et al. (2014), there are three forms of cooperation on the use of machines in Hungary: machinery work based on reciprocity, lending machines to each other, and joint ownership, procurement and use of agricultural machines. The use 
of technical resources on farms is low, only $25-26 \%$. The increase in the number of machines on farms does not mean their greater utilization. In order to use machines more efficiently, the authors recommend sharing machines within the MR. In this way, the problem of excess capacity on large farms and deficiency of machinery on small farms is solved, and fixed and total costs of machine usage are reduced.

The procurement and use of joint machinery reduced costs by $65 \%$ for small farms and $30 \%$ for large farms, as well as fixed costs by $30-46 \%$ for the purchase of own agricultural machinery (Colson, 2008). After a machinery sharing arrangement involving the purchase and use of joint machines, investments on the farm were reduced to 620 euros per ha, as opposed to 3324 euros per ha invested before associating in the machinery ring (Takacs and Takacs, 2012).

On family farms in Croatia (in the Osijek-Baranja County), the rate of utilization of tractors of up to 75 $\mathrm{kW}$ is in the range of $26-94 \%$, and for tractors over 75 $\mathrm{kW}$ it is $26-78 \%$ (Zimmer, 2019). In the Republic of Croatia, farms are well equipped with agricultural machinery, but machinery use is low due to the small size of plots. One solution to increase the level of machinery utilization and reduce its costs can be the joint use of machines (Grgić, 1998).

Stojanović et al. (2001) reported that, in Koprivnica and Zagreb counties, a tractor with an average power of $34.48 \mathrm{~kW}$ with 4.6 attached machines cultivates 9.05 ha of land. The annual utilization of tractors is only 180 hours, and of attached machines 39.6 working hours. In a study by Šumanovac (1996), the use of tractors on agricultural farms was not sufficient. The tractor with a power of $29 \mathrm{~kW}$ had the highest efficiency of 0.57 . The rational use of tractors could be increased by the joint use of agricultural machines in the MR, following the experience of some countries in Germany, France, Slovenia, Hungary, the USA and others.

For the successful functioning of the MR with low unit costs, it is necessary to provide highly productive machines and coordinate their productivity with the scope of planned work with good logistical support, planning and organizing (Božić et al. 2010, Topisirović et al. 2007).

In Germany, about 300 MRs have been established with close to 200,000 members, and $36 \%$ of farms within the MRs cultivate $45 \%$ of agricultural land. In Slovenia, in 2007, there were 45 MRs with 5,755 members, who cultivated an area of 61,112 ha with 137,295 hours of machinery operation (Pajić et al. 2014).

During the initial starting period in 2005, the Agrokrug (Agrocircle) machinery ring from Bačko Petrovo Selo cultivated 70 ha using 8 tractors and 80 joint machines, and in 2016, the total cultivated land area was about 300 ha (Tot, 2013; Radić et al., 2016; Pajić et al., 2014; Veljković et al., 2020).

An example of a well-organized MR is the "Circle of Machines" in Brčko, where 13 machine rings with 41 tractors and over 300 attachments cultivate 30,000 ha of land with 600 members and 1,500 service users (Veljković et al. 2009, Nešić and Radić, 2003).

The goal of this research was to determine the seasonal performance (in hectares and tones) of combines shared in the MRs in Montenegro. Due to the rational use of silage harvesters, large areas under fodder crops for silage preparation (from whole-plant corn , grass, a mixture of legumes, and small grains) were cultivated in the MRs, which required greater utilization of tractors and attachments.

\section{Material and methods}

The research was conducted in the municipalities of Bijelo Polje, Berane and Pljevlja as part of the project "Assistance in the development of livestock breeding in the mountainous areas of Montenegro and Kosovo" funded by the Food and Agriculture Organization of the United Nations (UN FAO). In the northern part of Montenegro, a total of 15 MRs with 92 farmers have been formed in the mentioned municipalities (Koprivica et al. 2010a, Koprivica et al. 2020). The research included 7 machinery rings (MRs) and 45 farmers, of which 20 farmers shared 6 silage harvesters intended for the preparation of silage from different plants.

The total seasonal harvesting performance of silage combines was obtained by summing up the total harvested area and quantities of prepared silage across members and by providing services to non-members of the MRs. The methodology covered the structure of agricultural land, crop structure, the availability of agricultural machinery, and machine operation on the farms in the MRs.

In 2 MRs in the municipalities of Bijelo Polje and Berane, the seasonal performance of one SIP SK 80 B combine used jointly by 9 farmers for the preparation of whole-plant corn silage was monitored. In addition, in 4 MRs uniting 6 farmers seasonal performance was evaluated for two Uzel combines used for direct mowing and ensiling, and one Feraboli combine used for silage preparation from mown grass, , legumes and cereals. In the municipality of Pljevlja, in 3 MPs uniting 5 farmers, the performance of two Corner Machinery harvesters used for direct mowing and chopping of grass, peas, legumes (common vetch) and oats was determined.

\section{Results and Discussion}

Areas for the production of bulk fodder in the investigated area mainly include hilly mountainous areas, and hay from natural grasslands is used as bulky fodder. Natural grasslands are significant resources in the production of bulk fodder in hilly mountainous areas (Tomić et al. 2018). It is possible to increase the production of bulky fodder on grasslands by applying cultural practices such as mineral fertilization or by establishing new grasslands. After joining the MRs, farmers intensified the production of bulky fodder, cultivated natural grasslands and sowed new crops and combined crops of legumes (peas and legumes) and oats for silage. Silage corn was sown in river valleys and in areas with favorable environmental conditions. In the study area, farmers did not prepare silage before the formation of the MRs, since they did not have adequate mechanization. After the formation of the MRs, two Turkish combines i.e. one Corner Machinery and one Uzel- model 1300 were procured for shared use by farmers. These combines are intended for the preparation of grass silage, legumes, cereals, mixed legumes with cereals and sorghum, as well as for mowing grass to be used as fresh, green feed. During operation, the combine mows, chops and loads the harvested biomass into the transport trailer (Koprivica et al. 2010, Koprivica et al. 2012). 
Table 1

The seasonal performance of combine harvesters for silage by types of silage in the MRs of Bijelo Polje and Berane

\begin{tabular}{|c|c|c|c|c|c|c|c|}
\hline \multirow[t]{3}{*}{ Machinery ring } & \multirow{3}{*}{$\begin{array}{l}\text { Farm } \\
\text { designat } \\
\quad \text { ion }\end{array}$} & \multicolumn{6}{|c|}{ Types of silage } \\
\hline & & \multicolumn{2}{|c|}{ Alfalfa } & \multicolumn{2}{|c|}{ Vetch and oats } & \multicolumn{2}{|c|}{ Peas and oats } \\
\hline & & ha & $\mathrm{t}$ & ha & $\mathrm{t}$ & ha & $\mathrm{t}$ \\
\hline \multirow{3}{*}{ Bor } & $\mathrm{A} 1$ & 1.0 & 24.28 & 0.5 & 26.3 & 0.4 & 16.52 \\
\hline & $\mathrm{A} 2$ & 0 & 0 & 0.25 & 12 & 0.5 & 19.75 \\
\hline & $\mathrm{A} 3$ & 0 & 0 & 0.3 & 15.9 & 0.5 & 20.8 \\
\hline Zaton & B1 & 0 & 0 & 0.5 & 33 & 0.3 & 15.69 \\
\hline Tomaševo & C1 & 0 & 0 & 0.2 & 12 & 0.4 & 20.96 \\
\hline Korita & D1 & 0 & 0 & 0.7 & 41.2 & 0.5 & 23.9 \\
\hline Total & 6 & 1.0 & 24.28 & 2.45 & 140.4 & 2.6 & 117.62 \\
\hline
\end{tabular}

Proper selection of the optimal number of appropriate machines in MRs enables sustainable production and ensures desired economic and production results. Good organization entails the use of available shared machines under the optimal terms and conditions.

For the first time, farmers from the MRs in Bor and Korita were able to prepare grass silage and silage from a mixture of legumes, peas and legumes with small grains. In the MR in Bor, of a total of 5 farmers, 3 decided to use a joint combine to prepare silage. All three farmers used the combine to prepare legume and cereal silage, and one farmer also used it for alfalfa silage (Table 1).
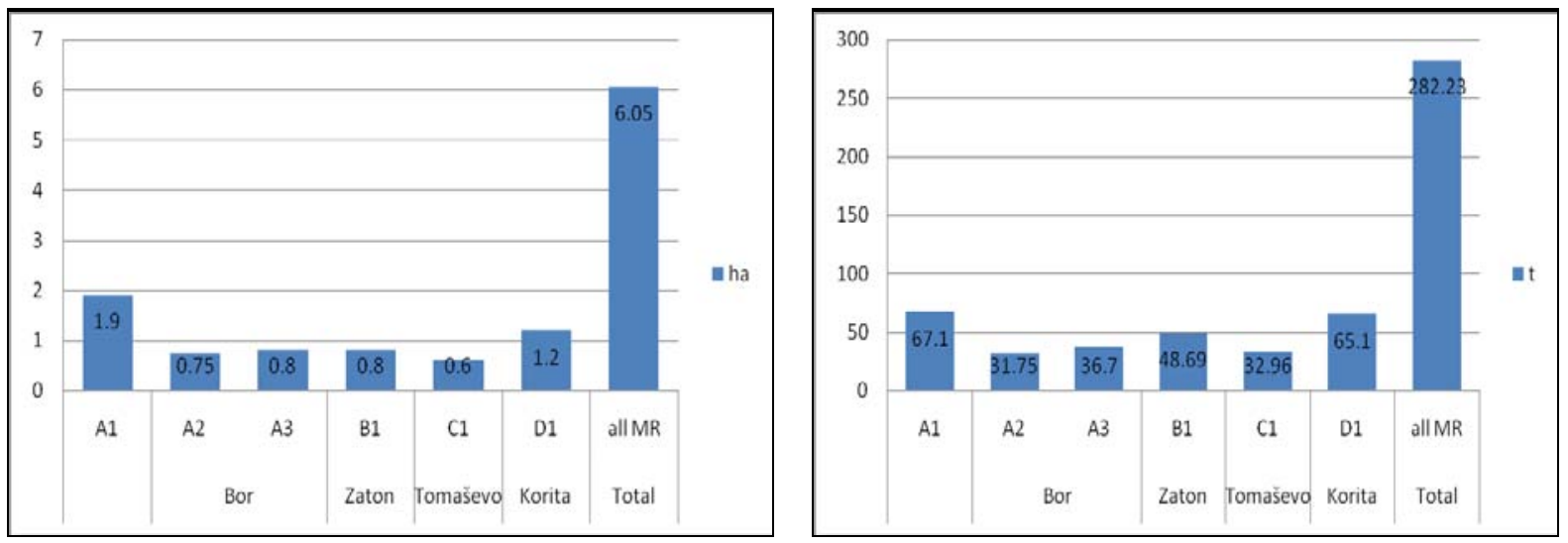

Figures 1, 2. The seasonal performance of combine harvesters expressed through the harvested area and amount of silage in MRs on farms in the municipalities of Bijelo Polje and Berane
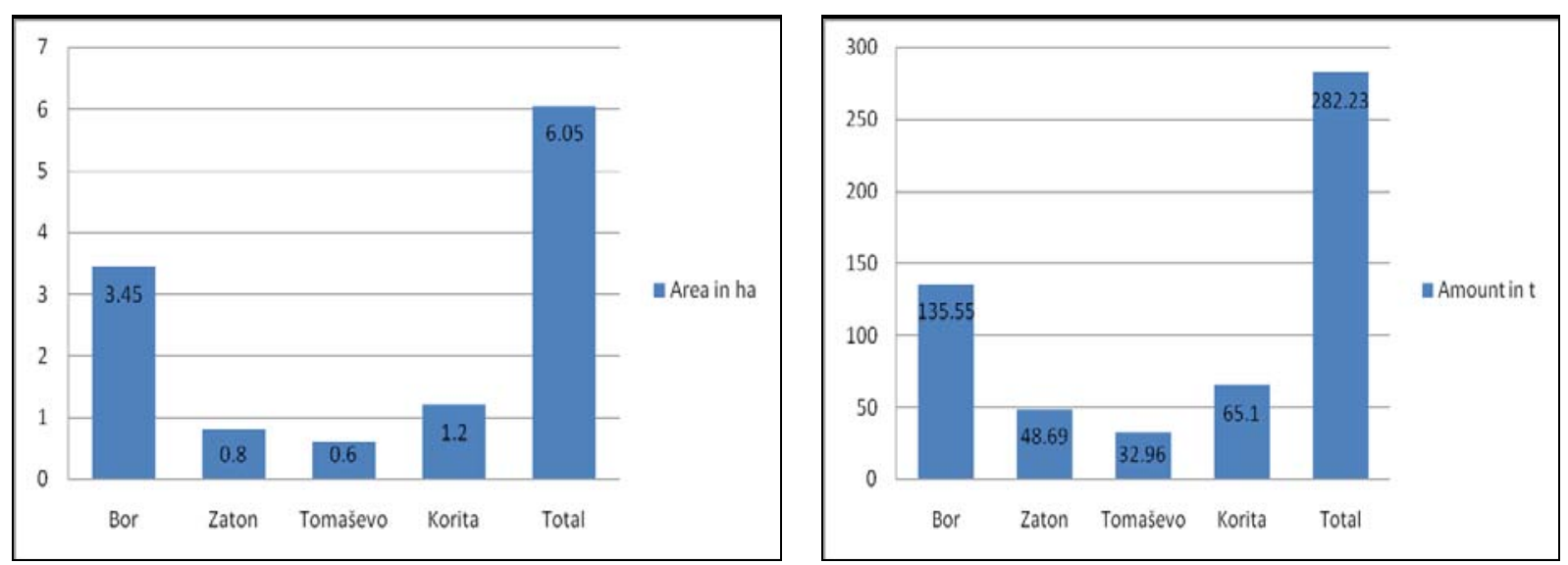

Figures 3, 4. Total seasonal performance of combine harvesters for silage by harvested area and amount of silage in the MRs in Bijelo Polje and Berane

Graphs 1, 2, 3 and 4 present the seasonal performance (in hectares and tons) of combines on farms in machinery rings. The shared harvester in the MR in Bor harvested 3.45 ha of land and $135.55 \mathrm{t}$ of silage from harvested plants (Figures 3,4 ). In the MR in Korita, out of 5 members in total, the combine was used by only one farmer (on farm D1) for the preparation of silage from legumes, peas and oats, and achieved a total seasonal performance of 1.2 ha and $65.1 \mathrm{t}$ silage. The same combine was used by a farmer in the MR in Zaton (farm B1) for silage preparation on 0.8 ha of land, from which he harvested 48.69 tons of silage (Table 1 and Figures 1, 2, 3, 4).

The joint Feraboli combine harvester was used in the MR in Tomaševo for the preparation of silage from cuts of the same plants and achieved a seasonal 
performance of 0.6 ha and 32.96 t silage (Figures 3,4 ). The total seasonal performance of 3 joint harvesters used for silage preparation from various plants by 6 farmers in 4 MRs in the municipalities of Bijelo Polje and Berane was 6.05 ha and $282.23 \mathrm{t}$ (Figures 3, 4).

For corn silage preparation in the MR of the same municipalities, a combine was used in the MR in Zaton by 3 farmers on an area of $7.4 \mathrm{ha}$, and in the MR in Tomaševo by 6 farmers on 6.2 ha of land. The same combine was hired for the preparation of silage on 1.2 ha in the Đurđevi Stupovi (Pillars of St. George) Monastery (farm M) in Berane. The total seasonal yield of the combine was 14.9 ha of harvested land, and $468.45 \mathrm{t}$ of corn silage. The greatest amount of corn silage was prepared in the MR in Zaton on farm A1, since this farm was engaged in more intensive livestock production (Table 2).

\section{Table 2}

The seasonal performance of combines for corn silage in the MRs in Bijelo Polje and Berane

\begin{tabular}{|c|c|c|c|c|}
\hline \multirow{2}{*}{$\begin{array}{l}\text { Machinery ring } \\
\text { MR }\end{array}$} & \multirow{2}{*}{$\begin{array}{l}\text { Farm } \\
\text { designation }\end{array}$} & \multicolumn{3}{|c|}{ Corn silage } \\
\hline & & Surface area ha & Amount mass $\mathrm{t}$ & Yield t/ha \\
\hline Zaton & $\begin{array}{l}\text { B1 } \\
\text { B2 } \\
\text { B3 }\end{array}$ & $\begin{array}{l}5.5 \\
1.0 \\
1.0\end{array}$ & $\begin{array}{c}150.15 \\
33.3 \\
35.0\end{array}$ & $\begin{array}{l}27.3 \\
33.3 \\
35.0\end{array}$ \\
\hline Total MR & 3 & 7.5 & 218.45 & $\bar{X}=31.87$ \\
\hline Tomaševo & $\begin{array}{l}\text { C1 } \\
\text { C2 } \\
\text { C3 } \\
\text { C4 } \\
\text { C5 } \\
\text { C6 }\end{array}$ & $\begin{array}{l}1.5 \\
1.0 \\
1.2 \\
1.0 \\
1.0 \\
0.5\end{array}$ & $\begin{array}{c}60.0 \\
32 \\
42 \\
30.0 \\
41.0 \\
15.0 \\
\end{array}$ & $\begin{array}{c}40.00 \\
32.0 \\
35.0 \\
30.0 \\
41.0 \\
30.0 \\
\end{array}$ \\
\hline Total MR & 6 & 6.2 & 220.0 & $\bar{X}=34.67$ \\
\hline Other (service) & $\mathrm{M}$ & 1.2 & 30.0 & 25.0 \\
\hline Total & 10 & 14.9 & 468.45 & 31.44 \\
\hline
\end{tabular}

In the municipality of Pljevlja, 3 MRs were formed and 2 Corner Machinery combines were procured. The first combine in the MR in Lijeska and Adrovići was used by 2 farmers who made up $33.33 \%$ of the total number of farmers. The total seasonal performance of the combine was 6.7 ha and $172.92 \mathrm{t}$ of silage from sown grasses, legumes and a legume-oat mixture (Table 3, Figures 5, 6, 7, 8).

Table 3

The seasonal performance of a combine for silage by types of silage in the MR Pljevlja

\begin{tabular}{|c|c|c|c|c|c|c|c|}
\hline \multirow[t]{3}{*}{ Machinery ring } & \multirow{3}{*}{$\begin{array}{l}\text { Farm } \\
\text { designat } \\
\text { ion }\end{array}$} & \multicolumn{6}{|c|}{ Types of silage } \\
\hline & & \multicolumn{2}{|c|}{ Sown meadow } & \multicolumn{2}{|c|}{ Red clover } & \multicolumn{2}{|c|}{ Vetch and oats } \\
\hline & & ha & $\mathrm{t}$ & ha & $\mathrm{t}$ & ha & $\mathrm{t}$ \\
\hline Lijeska & F1 & 2.7 & 79.92 & 0 & 0 & 1.0 & 15.0 \\
\hline Adrovići & $\mathrm{F} 2$ & 3.0 & 78.0 & 0 & 0 & 0 & 0 \\
\hline Kruševo & G1 & 3.8 & 60.8 & 0 & 0 & 3 & 60 \\
\hline \multirow{2}{*}{ Glibaći } & H1 & 1.0 & 20 & 0 & 0 & 0.9 & 27 \\
\hline & $\mathrm{H} 2$ & 1.5 & 30.3 & 1.0 & 34.5 & 0 & 0 \\
\hline Total & 5 & 12 & 269.02 & 1 & 34.5 & 4.9 & 102 \\
\hline
\end{tabular}
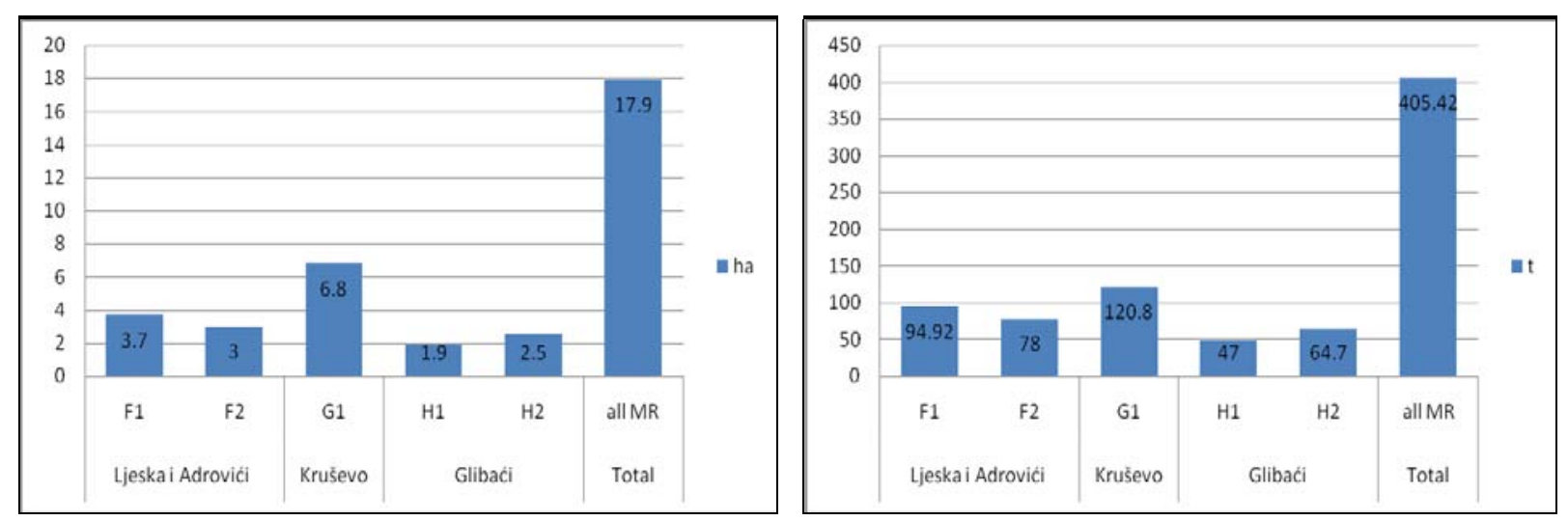

Figures 5, 6. The seasonal performance of a combine expressed through harvested area and amount of silage in the MR on farms in the municipality of Pljevlja 

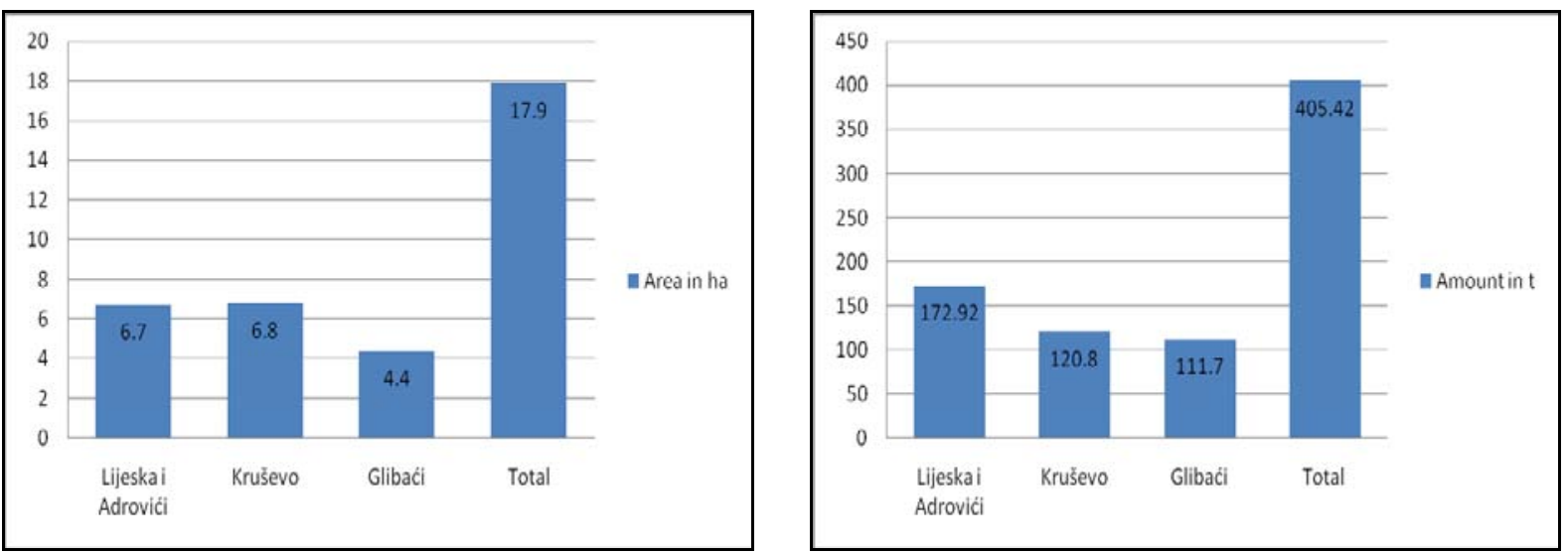

Figures 7, 8. Total seasonal performance of a combine for silage by harvested area and amount of silage in the MR in Pljevlja

The second combine was used for silage preparation by only 3 farmers of a total of 17 farmers in the MRs in Kruševo and Glibaći. The total performance of the combine for grass silage preparation during the season was 6.3 ha and $111.11 \mathrm{t}$, and for red clover silage 1 ha and 34.5 t. In addition, for two farmers in this MR, during the season, the combine achieved a yield of 3.9 ha and $87 \mathrm{t}$ silage of legume and oat (Table 3). The total seasonal performance of this combine in the MR Kruševo and Glibaći was 11.2 ha and $232.6 \mathrm{t}$ of silage from the mentioned plants (Figures 5, 6). Figures 5 and 6 show the seasonal performance (in hectares and tons) of the combine on farms in the MR in Pljevlja.

In studies by Koprivica et al. 2010b and Koprivica et al. 2012, the Corner Machinery harvester achieved a production output of $0.14-0.21$ ha per $h$ and 5.81-7.89 $\mathrm{t}$ per $\mathrm{h}$, depending on speed, working width, yield, plot size and work organization. During the season, the combine were used in the MRs in Kruševo 8 days, Glibaći 6 days, Lijeska 9 days (with interruptions due to rain), Adrovići 5 days, Bor 6 days, Korita 3 days, Zaton 4 days (with interruptions due to rain) and Tomaševo 4 work days.

The capacity of the Feraboli combine was insufficiently used because it worked only 4 days on one farm. The combine could not work continuously because the plots were small and the slope of the ground was steep; therefore, the harvested biomass was transported to the farm, where it was prepared and placed in silage storage facilities.

The combines for the preparation of whole-plant corn silage were used by farmers 10 and 7 days in the MRs in Tomaševo and Zaton, respectively, and 2 days at the Monastery.

\section{Conclusions}

In 7 machine rings, 4 silage combine harvesters intended for direct mowing and one combine with a pick-up front were shared for lifting the biomass and for the preparation of silage from grass and a mixture of legumes and grain. The performance of a combine for preparing corn silage in two machine rings was determined on 9 farms. The joint machines were unevenly used in the MR. In 7 MRs, only 11 farmers or $24.44 \%$ of the total number of farmers shared silage harvesters for direct mowing. The joint combine for the preparation of silage from whole corn plants was used in 2 MRs by 9 farmers or $75 \%$ of the total number of farmers.

Other farmers showed interest in preparing silage, but the insufficient number and low performance of the combines were the limiting factors. The extent of use of shared silage harvesters depends on the area under fodder plants, the operating performance of the combine, optimal dates for cultural operations, and weather conditions, i.e. the number of days suitable for work. Based on the well-planned production and sowing of legumes and grain, as well as the wellplanned joint use of machinery in the Machinery Ring $M R$, the silage preparation season and use of silage harvesters have been prolonged. In this way, the effects of the seasonal utilization of combines increased, because they were used not only for ensiling grass, but also for combined crops of legumes and oats. Combines for ensiling grass and a mixture of legumes and cereals worked a total of 45 days during the season, and those for preparing silage from whole corn plants worked 19 days. During the silage preparation season, the total annual utilization of tractors in the MRs increased for operations such as cultivation, seedbed preparation, sowing, crop care, mowing, chopping, transport and trampling of silage from whole corn plants, as well as legumes and cereals.

\section{Acknowledgments}

The research was supported by the Ministry of Education, Science and Technological Development, Republic of Serbia.

\section{References}

Baranyai, Z., Szabo, G., Vasary, M. (2014). Analysis of machine use in Hungarian agriculture- Is there any future for machinery sharing arrangements. Roczniki (Annals), Polish Association of Agricultural Economists and Agribusiness. Stowarzyszenie Ekonomistow Rolnictwa $e$ Agrobiznesu (SERiA) vol. XVI (3), 24-29.

Božić, S., Radojević, R., Dražić, M. (2010). Dijagnostika sredstava mehanizacije mašinskih prstenova, Poljoprivredna tehnika, 3, 35-43.

Colson, G. (2008). Alternative approaches for sharing machinery, labor, and other resources among small- and medium-sized agricultural producers, Retrospective Theses and Dissertations, https://doi.org/10.31274/rtd180813-16557

Grgić, Z. (1998). Iskorištenje poljoprivredne mehanizacije u voćarskoj proizvodnji obiteljskih gospodarstava Zbornik 
radova 26. savjetovanja „Aktualni zadaci mehanizacije poljoprivrede“" Opatija, 49-54.

Koprivica, R., Veljković, B., Dedić, T., Martinov, S. (2010a). Rezultati osnivanja mašinskih grupa u sjeveroistočnom dijelu Crne Gore Results on the establishment of machinery groups in northeastern Montenegro. Poljoprivredna tehnika, 35(3), 25-34.

Koprivica, R., Thaqi, A., Sharku, A., Kida, S. (2010b). Operating characteristics of a "Corner machinery -1300" tractordrawn forage harvester in alfalfa silage preparation, $21^{\text {st }}$ Scientific-Expert Conference of agriculture and food industry, Proceedings, Neum, Bosnia and Herzegovina, 427-435.

Koprivica, R., Veljković, B., Radivojević, D., Đurišić, J., Dedić, T., Mileusnić Z. (2020). Sustainable functionality of machinery rings in the northern part of Montenegro, GEA (Geo Eco-Eco Agro) International Conference, 28-31 May 2020, Montenegro Book of Abstracts 252. GEA

Koprivica, R., Veljković, B., Radivojević, D., Stanimirović, N., Topisirović, G., Đokić, D. (2012). Grass silage making by direct cutting using Corner Machinery - 1300 flail forage harvester. African Journal of Agricultural Research, 7(40), ,5459-5465.

Nešić, D., Radić, P. (2003). Pružanje mašinskih usluga kako to drugi rade?. Traktori i pogonske mašine, 8(5), 51-56.

Pajić, M., Radojičić, D., Gligorević, K., Dražić M., Oljača M., Zlatanović I. (2014): Stanje i perspective mašinskih prstenova u savremenoj poljoprivrednoj proizvodnji. Zbornik radova, 17. Naučno stručni skup "Aktuelni problem mehanizacije poljoprivrede", Beograd, Srbija, 122-132.

Radić, P., Pajić, M., Karolj, P. (2016). The first active machinery ring in Republic of Serbia. Proceedings, $18^{\text {th }}$ Scientific Conference Current problems and tendencies in agricultural engineering, Belgrade, 9.12.2016. Serbia, 139-143.

Stojanović, M., Bošnjak, J., Kušec, V. (2001). Iskorištenost poljoprivredne mehanizacije na obiteljskim gospodarstvima. Zbornik sažetaka 37. znanstvenog skupa hrvatskih agronoma s međunarodnim sudjelovanjem, Opatija, Hrvatska, 167.

Šumanovac, L. (1996). Racionalno korištenje sredstava poljoprivredne mehanizacije na obiteljskim gospodarstvima. Doktorska disertacija. Sveučilište Josipa Jurja Strossmayera u Osijeku, Poljoprivredni fakultet u Osijeku, Osijek.

Takacs, I., Takacs, G.K. (2012). Cooperation among farmers for cost saving machinery. Proceedings, $3^{\text {rd }}$ International Symposium "Agrarian Economy and Rural Development realities and perspectives for Romania", Bucharest, Romania, October 11-13, 2012, 320-335.

Tot, A. (2013). Jedna mogućnost racionalnije nabavke i korišćenja poljomehanizacije. Traktori i pogonske mašine, 18(1), 86-94.

Topisirović, G., Koprivica, R., Radivojević, D., Stanimirović, N. (2007). Prvi rezultati osnivanja mašinskih prstenova i primena mašina za pripremu travne silaže u brdskoplaninskom području. XI simpozijum o krmnom bilju, Zbornik radova Instituta za ratarstvo i povrtarstvo Novi Sad, 44(1), 547-555.

Tomić, D., Brković, D., Stevović, V., Bokan, N., Đurović, D., Lazarević Đ. (2018). Productivity of natural grassland of the order Arrhenatheretalia depending on nitrogen fertilization level. Acta Agriculturae Serbica, 23(46), 187196.

Veljković, B., Koprivica, R., Milošević, T., Radivojević, D., Broćić, Z. (2020). Udruživanje u funkciji održivog ruralnog razvoja. Agroekonomika , 49(86), 1-11.

Veljković, B., Koprivica, R.,Topisirović, G., Stanimirović, N. (2009). Mašinski prstenovi kao oblik udruživanja poljoprivrednih proizvođača. XIV Savetovanje o biotehnologiji, Agronomski fakultet Čačak, Zbornik radova, 14(15), 505-512.

Zimmer, D. (2019). Optimalno opremanje poljoprivrednih gospodarstava sredstvima poljoprivredne mehanizacije. Doktorska disertacija. Fakultet agrobiotehničkih znanosti Osijek Sveučilište Josipa Jurja Strossmayera u Osijeku. 